Prof. dr. Izet ŠABOTIĆ

Filozofski fakultet Univerziteta u Tuzli

E-mail: sabota_tuzla@hotmail.com

ORCID: 0000-0002-6514-8618

Stručni rad/Professional article

UDK/UDC: 94:33(497.6)"18/19""1945/1952" Hadžić S. (049.3)

DOI: https://doi.org/10.52259/historijskipogledi.2021.4.6.371

\title{
Senaid Hadžić, VELIKI ZAOKRET: Bosna i Hercegovina u vremenu tranzicije (od 1880-ih do 1950-ih), Centar za istraživanje moderne i savremene historije Tuzla i Arhiv Tuzlanskog kantona, Tuzla 2021, 493 str.
}

Socijalistički period bosasnskohercegovačke prošlosti nije u dovoljnoj mjeri istraživan, iako je radi ovaj period obilježen velikim zaokretom i brojnim događajima. To seposebno odnosi na njenu privrednu (ekonomsku) komponentu. $\mathrm{O}$ ovom pitanju napisano je nekoliko članaka i priloga, dok su historijski sadržaji u vidu sinteza uglavnom izostali. Stoga, tretiranje ove problematike predstavlja važan pomak i doprinos bosanskohercegovačkoj historiografiji. Stoga knjiga prof. dr. Senaida Hadžića u tom pogledu predstavlja značajnu novinu, iz razloga što se navedeno pitanje, po prvi puta na ovakav sveobuhvatan i temeljit način tretira. Bogata historiografska osnova, te struktura i raznovrsan sadržaj ukazuju da je riječ o vrijednom naučnom poduhvatu. Očito je, da je autor knjige bio svjestan složenosti navedene tematike, što potvrđuje sveobuhvatno i temeljito tretiranje navažnijih pitanja koja zadiru u srž problematike. U Uvodu knjige, dat je detaljan osvrt na literaturu i dosadašnji nivo istraženosti ove kompleksne teme.

Otvoranjem prvog tematskog poglavlja, pod nazivom: OSOBENOSTI TRANZICIJE BOSNE I HECEGOVINE DO 1945 GODINE, obrađeno je nekoliko pitanja koja nas na jednostavan i pregledan način uvode u naznačenu problematiku. Važno pitanje se odnosi na tranziciju bosanskohercegovačkog društva na prelazu iz 19. u 20. stoljeće, pri čemu je ukazano na jačanje industrijske komponente, što je imalo uticaja ne samo na ekonomske, već i ukupne prilike u Bosni i Hercegovini u navedenom vremenu. Industrijski razvoj je doveo do snaženja privrede, što se odrazilo i na ukupna društvena kretanja. Rezimiran osvrt dat je i na privredne prilike u vremenu između dva svjetska rata (1918-1941), pri čemu je ukazano na značajnu privrednu stagnaciju, a što je rezultat ciljane zvanične politike koja se vodila iz Beograda prema Bosni Hercegovini. Privredna stagnacija, se odrazila na sve segmente života, što je sveukupno uticalo na očito siromašenje bosanskohercegovačkog društva. 
U vrijeme Drugog svjetskog rata ne samo da je došlo do dalje stagnacija privrede u Bosni i Hercegovini posebno već i njene devastacije $\mathrm{i}$ urušavanja. Uništena su brojna industrijska postrojenja, a ono što je radilo, radilo je sa značajno reduciranim kapacitetom i uglavno za potrebe okupatorskih snaga. Posebno je u knjizi naznačeno pitanje iskorištavanja rudnog bogastva $\mathrm{i}$ šumskih potencijala od strane okupatorskih snaga. Takva eksploatacija nije posticala privredni razvoj, već je uticala na još veću devastaciju bosanskohercegovačkih resursa u vrijeme Drugog svjetskog rata.

Kao i drugi prostori tadašnje zajedničke države DFJ, i Bosna i Hercegovina je iz Drugog svjetskog rata izašla sa ogromnim ljudskim gubicima i stradanjem privrednih kapaciteta. Stoga je u knjizi ovom pitanju posvećena posebna pažnja kroz poglavlje: PERIOD OBNOVE BOSNE I HERCEGOVINE.

Detaljan osvrt je dat na ukupno stanje pred kraj Drugog svjetskog rata i uspostavljanje organa nove vlasti, te ukazano na brojne probleme sa kojima se vlast sretala. U sklopu ovog pitanja predočeno je naslijeđeno stanje, koje je bilo jako složeno, zemlja je bila u ruševnom stanju, uništeni su privredni subjekti, razorena infrastruktura. Sve je to

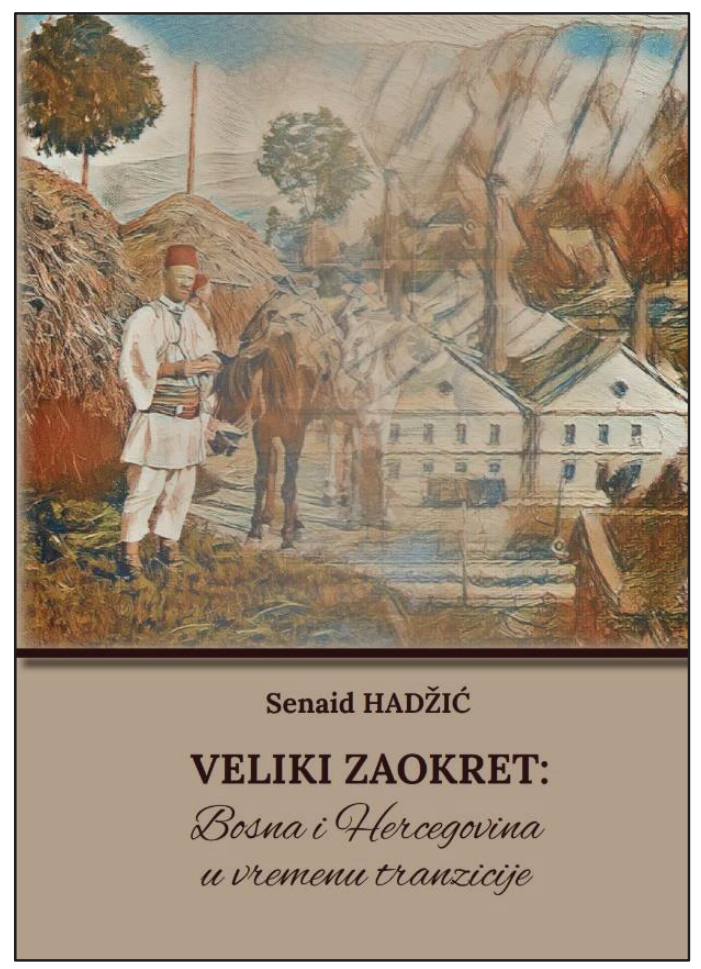
otežavalo normalizaciju života neposredno nakon Drugog svjetskog rata. Stanje je značajno usložnjeno, velikim ljudskim gubicima, što se odrazilo na ukupne prilike u zemlji. Na ukupne okolnosti značajnog uticaja imale su infrastrukturne prilike i elektropostrojenja, koja su trebala biti važnom osnovom obnove i daljeg privrednog razvoja u zemlji. Ukazano je da je u prvim poslijeratnim godinama poljoprivreda predstavljala važnu ne samo privrednu, već i ukupnu životnu komponentu. U tom pogledu provođeni su važni procesi u oblasti agrara, među kojima je najvažnija bila agrarna reforma i kolonizacija, te kolektivizacija sela, ali i konfiskacija i eksproprijacija zemlje, te uvođenje agrotehničkih mjera bili su važni procesi u oblasti agrara. Cilj je bio obezbijediti neophodnu hranu stanovništvu, a kroz dobrovoljni zajedničkikolektivni rad u oblasti poljoprivrede. 
Detaljano je u ovom poglavlju prikazano stanje u oblasti industrije, te ukazano na uništavanje industrijskih postrojenja, na njihovu obnovu i puštanje u proizvodnju. Više industrijskih preduzeća je obnovljeno već u prvoj poslijeratnoj godini, što je bio podsticaj za dalji i brži industrijski razvoj. Kroz poseban sadržaj predstavljena su osnovna obilježja privredne politike, gdje su poljoprivreda i industrija bile glavne grane razvoja, što se vidjelo i kroz privredne rezultate u prvim godinama nakon Drugog svjetskog rata. Obnovljeni su brojni u ratu stradali privredni objekti, sačinjeni novi, urađena infrastruktura, pri čemu je posean značaj imala izgradnja pruga Brčko-Banovići i Šamac Sarajevo. Sve je to pružalo dobru osnovu za dalji razvoj zemlje nakon Drugog svjetskog rata.

Do bržeg privrednog razvoja i tranzicije bosanskohercegovačkog društva došlo je u narednom periodu, što je detaljno predstavljeno u posebnoj tematskoj cjelini, pod nazivom: UTICAJ INDUSTRIJE NA TRANZICIJU BOSANSKOHERCEGOVAČKOG DRUŠTVA 1947-1948. U ovom poglavlju dat je kratak, ali jasan presjek geopolitičkog konteksta i historijskog naslijeđa, pri čemu je ukazano da je to iznimno važna osnova za prelazak sa ratne na plansku privrednu izgradnju na nivou tadašnje zajedničke države. Za taj važan planski zadatak izvršeni su neophodne pripreme. Sve to je davalo nadu u bolje sutra, te je kod stanovništva bio prisutan veliki elan u provođenju i realizaciji brojnih poslijeratnih privrednih projekata. $\mathrm{Na}$ tom planu, značajan iskorak je bio prvi Petogodišnji plan (1947-1952), kojem je u knjizi posvećena posebna pažnja. Posebno se ukazalo na značaj ovog plana za Bosnu i Hercegovinu, pri čemu je ukazano na njegove najznačajnije zadatke. Ovaj plan se smatrao jednim od najvažnijih zaokreta u zemlji na privrednom planu, da je to projekat koji je nudio novi privredni prosperitet, ali koji je zahtijevao brojna odricanja samog stanovništva, a sve kako bi se stvorila dobra privredna osnova za brži i sveobuhvatniji razvoj zemlje. U navedenim aktivnostima realizacije Prvog petogodišnjeg plana i uspostave novog etatističkog sistema nailazilo se na veliki broj problema i otvorenih pitanja, koji su se odnosili na nedostatak neophodnih finansijskih sredstava, manjak adekvatnog kadra sposobnog da sprovede navedene mjere, slaba podrška iz vana i dr. Navedeni "etatistički" sistem podrazumijevao je napuštanje nekih privrednih grana, poput poljoprivrede i zanatstva, na uštrb razvoja industrije. To je podrazumijevalo ne samo akumulaciju i usmjeravanje finansijskih sredstava u oblasti industrije, već i značajnu fluktaciju radne snage na relaciji selo-grad. Ovim mjerama i procesima bosanskohercegovačko društvo počinje da se mijenja u socijanostatusnom pogledu i da se prilagođava novim formama privređivanja i života, što nije bilo uopšte lako.

Jedno od krucijalno važnih pitanja, bilo je pitanje obezbijeđenja dovoljnih količina hrane za stanovništvo. U tom pogledu su provođene brojne mjere na planu obezbijeđenja snadbijevanja stanovništva. Na ovaj način država je uspjela uspostaviti kontrolu u svim segmentima svog gledanja, kreirajući 
jedan novi privredni sistem, koji je pratio ono što se dešavalo u privrednom pogledu.

Veliki uticaj Sovjetskog saveza bio je prisutan u svim segmentima života i razvoja jugoslovenske države. Na tom planu postojali su brojni sporazumi i dogovori, što je trebalo biti potvrda da ista ide u pravcu socijalizma kakvog je zagovarao sovjetski politički vrh na čelu sa Staljinom. Međutim, u jugoslovenskom razvoju socijalizma došlo je do određenih odstupanja, u odnosu na ono što je očekivao Sovjeski Savez sa ostalim socijalističkim državama sa kojima je bio integrisan u zajedničku organizaciju poznatu kao Informbiro. Te razlike u viđenju razvoja zemlje i socijalizma uopšte, vodile su u otvoren sukob poznat kao sukob KPJ sa Informbirom. To je značilo novo stanje u svim segmetima života u zemlji, a posebno u oblasti privrede. Informbiro je osudio takvo djelovanje jugoslovenskog političkog vrha, te prekiuo političku i privrednu suradnju sa zemljom. Sukob sa Informbirom se snažno reflektovao i na druga polja i segmete jugoslovenskog društva. Došlo je do raskola i obračuna sa političkim neistomišljenicima, provođena je strahovlada i izvršen veliki pritisak na iste, a s druge strane jugoslovenski vrh je trpio ogroman pritisak od strane Sovjetskog saveza i drugih članica Infombiroa. Ovaj sukob je puno toga promijenio na privrednom planu, pa su se očekivali zastoji i zaokreti u već započetim privrednim aktivnostima vezanim za Prvi petogodišnji plan. Sukob sa Informbiroom se odrazio na cijelom području tadašnje zajedničke države, što se može najbolje vidjeti na primjeru djelovanja protiv tzv "muslimanske reakcije" do koje je došlo na području bogatog industrijskog bazena Tuzle i njene okoline. To je ustvari pokazalo kakva će se politika voditi na ovom području i da je ovaj rudarski kraj bio u privrednim projekcijama predviđen kao baza za iskorištavanje bogatih privrednih resursa $\mathrm{i}$ izgradnju teške-prljave industrije. Takva politika se generalno vodila na cijelom području tadašnje NR Bosne i Hercegovine, gdje je bilo otvoreno nekoliko složenih političkih pitanja, pa i samo nacionalno pitanje Muslimana, a što je u velikoj mjeri bilo povezano i sa privrednim kretanjima na ovom području, gdje se bilo protiv principa "Bosna-Bosancima". Na taj način suzbijan je samostalan privredni razvitak Bosne i Hercegovine. U pogledu potpune uspostave komunističke vlasti i kontrolisanja ukupnog stanja u zemlji, provedene su brojne mjere, među kojima su posebno bile represivne one koje su provođene pod paraolom očuvanja "tekovina revolucije". Ovaj metod se primjenjivao kako kroz političke tako i kroz privredne forme djelovanja, a sve s ciljem da se uspostovi potpuna kontrola i usmjere privredni i društveni tokovi onako kako je to zagovarala i trasirala KPJ. Na taj način stvarao se jasan ideološko-politički okvir, koji je imao potpun uticaj i na privredna kretanja na području Bosne i Hercegovine.

Kako je industrija bila predviđena kao osnovna-temeljna grana privrede, istoj se u zemlji posvećivala posebna pažnja. Iz tog razloga u knjizi je posvećeno posebno poglavlje pod nazivom: LJUDSKI RESURSI U INDUSTRIJI KAO OSNOVA TRANZICIJE BOSNE I HERCEGOVINE 1947- 
1948. U istom su dati zanimljivi statisčki podaci vezani za strukturu radne snage zaposlene u industriji, načinu i metodama mobilizacije radne snage, pitanju i rezultatima dobrovoljnog rada, kao i podizanju takmičarskog duha i izgradnji kulta vrijednosti kao formule moralnog uzdizanja i izgradnje socijalističke svijesti kod stanovništva. U okviru ove tematske cjeline obrađeno je pitanje radničke solidarnosti i radničkog snadbijevanje a sve u funkciji izgradnje socijalističke svijesti kod radnika.

Kako je industrija sve više uzimala zamaha njen uticaj na tranziciju je bio sve izraženiji i očitiji, stoga je ovo pitanje predstavljeno kroz posebno poglavlje, pod nazivom: UTICAJ INDUSTRIJE NA TRANZICIJU BOSNE I HERCEGOVINE 1948-1952. U ovom poglavlju obrađeno je više historijski važnih pitanja. Jedno je ono koje se odnosi na refleksije sukoba sa Informbirom na privredna, a posebno industrijska kretanja, a što je vezano na potrebu napuštanja prvobitnog privrednog plana, koji je bio naslonjen na Sovjetski Savez i zemlje socijalističkog bloka. S toga je jugoslovenska privreda išla u svom zasebnom pravcu razvoja, a kroz posebnu formu socijalističkog samoupravljanja, pod parolom "da se radnicima daju na raspolaganje fabrike $\mathrm{i}$ proizvodnja”. Ovaj proces je pratilo i pokušaj decentralizacije. Svi ti procesi su zahtijevali velika odricanja i napor, prije svega radničke klase, a i cjelokupnog stanovništva zemlje. Ukazano je da je ukupnom razvitku zemlje poseban akcent se dao na razvoj industrije, a podizanjem novih industrijskih pogona, u Bosni i Hercegovini su to bili oni koji su se odnosili na baznu industriju: metalurgiju, rudarstvo i hemijsku industriju. Tako da je industrija sve više imala uticaja na ukupne privredna kretanja. Takav trend do izražaja dolazi izgradnjom velikih industrijskih investicija, poput: Željezare u Zenici, Koksare u Lukavcu, Borca u Travniku i dr. Ulaganja u velike industrijske komplekse dodatno je opteretilo finansije države, pa je u narednom periodu uslijedio postepeni pad investicija $\mathrm{i}$ ulaganje u industrijska postrojenja, mada je industrija već bila primarna privredna grana $\mathrm{u}$ zemlji. Forsiranim razvitkom industrije $u$ ukupnim privrednim relacijama došlo je do znatnog stagniranja drugih privrednih grana, posebno u oblasti poljoprivrede i zanatstva, o čemu se u knjizi donose zanimljivi pokazatelji. Ono što je također bilo primjetno $u$ vremenu industrijskog razvoja, jeste da on nije bio ravnomjerno razvijan na cijelom prostoru zajedničke države. Nešto izraženija finansijska sredstva su ulagana na području Slovenije, Hrvatske i Srbije, dok su druge republike, među kojima i Bosna i Hercegovina značajno zaostajale u tom pogledu. I u samoj Bosni i Hercegovini nije bio ravnomjerno zastupljen proces industrijskog razvoja, o čemu je u samoj knjizi izneseno jako puno zanimljivih podataka.

Ukazano je da razvojem industrije u državnim odnosima i strukturi došlo do velikih promjena. Te promjene su bile posebno izražene u socijalnoekonomskoj strukturi radne snage u Bosni i Hercegovini u vremenu od 1949. do 1952, što je i predstavljeno u posebnom poglavlju u kojem su otvorena pitanja koja ukazuju da se u oblasti privrede zemlja suočavala sa značajnim brojem problema. Iako je industrija u početnoj fazi imala zamah, već nakon 
dvije godine investicionih ulaganja, proizašli su brojni problemi u oblasti industrije. Jedan od evidentnih problema odnosio se na nedostatak adekvatne radne snage, posebno one kvalificirane koja je trebala da odgovori složenim zahtjevima industrijalizacije. To je imalo uticaja na usporavanje započetog procesa industrijalizacije zemlje. Značajan broj novih radnika u oblasti industrije činilo je seosko stanovništvo, koje nije bilo vično obavljanju složenih industrijskih procesa. U knjizi je predočeno da je industrijalizacija, osim na ekonomske procese imala uticaja i na demografske, gdje je bio izražen značajan prelazak stanovništva sa sela u gradove. Određeni zastoji u oblasti industrije uticali su na trend opadanja broja zaposlenih u ovoj privrednoj grani, što je ukazivalo da proces industrijalizacije ide usporenim tokom. To je bila potvrda da zagovarani Prvi petogodišnji plan razvoja zemlje, nije imao planirani hod razvoja. Međutim, očito je bilo da je industrija bila privredna grana od koje se najviše očekivalo u ukupnom privrednom razvoju zemlje.

U knjizi je zanimljivo predstavljeno pitanje promjena u socijalnoekonomskoj strukturi radne snage, gdje je u odnosu na 1945. godinu porastao broj radnika u industriju u odnosu na broj onih kojima je poljoprivreda $\mathrm{i}$ zanatstvo bile glavne privredne grane. Stoga je istaknuto da su privredna kretanja, a posebno proces industrijalizacije, uticala ne samo na privredna, već i na ukupne društveno-političke odnose u društvu.

$\mathrm{Na}$ kraju je kroz sažet Zaključak, dat rezimiran presjek tranzicijskih promjena koje su se dešavale u oblasti privrede u Bosni i Hercegovini u navedenom vremenu, sa posebnim akcentom na njihov snažan uticaj na ukupne privredne i društvene prilike u zemlji.

Potrebno je istaći, da navedena knjiga predstavlja važan historijski sadržaj, koji se bavi privrednim procesima u Bosni i Hercegovini u vremenu od 1880-ih do 1950-ih godina. Ukazano je na glavne karakteristike navedene privredne komponente, koje su se odnosile na razvoj privrede počev od vremena austrougarske uprave, sa posebnim akcentom na period razvoja nakon Drugog svjetskog rata. Jasno su predstavlje faze razvoja, prva koja se odnosila na obnovu ratom porušene zemlje i davanja na značaju pitanju razvoja poljoprivrede. Druga tranzicijska faza vezana je za Prvi petogodišnji plan i forsiranje industrije. Iako je bilo određenih poteškoća na planu industrijalizacije, ipak ovaj proces je uticao na sve sfere života u zemlji, te je predstavljao najznačajniju privrednu granu. Industrijalizacijom je izvršena i tranzicija bosanskohercegovačkog društva, sa klasične seosko-poljoprivredne, prešlo se na novu industrijsko-gradsku komponetu.

U knjizi su na metodološki i naučno prihvatljiv način tretirana brojna pitanja vezana za bosanskohercegovačka privredna kretanja u vremnu od 19451953, u kojima su predočene sve okolnosti koje su se odnosile na trasformaciju i tranziciju bosanskohercegovačkog društva.

Navedena knjiga predstavlja jedan zaokružen historijski sadržaj o važnoj problematici koja nije $u$ dovoljnoj mjeri tretirana $u$ bosanskohercegovačkoj historiografiji. Stoga smatram, da je prof. dr. Senaid 
Hadžić ovom knjigom učinio važan iskorak, ponudivši historijskoj nauci važna orginalna saznanja o bitnoj historijskoj tematici kakva je razvoj industrije od austrougarskog vremna do prvih godina socijalističkog razvoja. Ova knjiga predstavlja važan doprinos bosanskohercegovačkoj historiografiji. 